\title{
Characterization of bioactive compounds, antioxidant activity and minerals in landraces of pumpkin (Cucurbita moschata) cultivated in Southern Brazil
}

\author{
Daniela PRIORI ${ }^{1 *}$, Eduardo VALDUGA², Juliana Castelo Branco VILLELA ${ }^{3}$, Claudete Clarice MISTURA ${ }^{1}$, \\ Márcia VIZZOTTO ${ }^{1}$, Ricardo Alexandre VALGAS ${ }^{1}$, Rosa Lía BARBIERI ${ }^{1}$
}

\begin{abstract}
The objective of this work was to evaluate the genetic variability for the synthesis of bioactive compounds and minerals in pumpkin (Cucurbita moschata) landraces. Total phenolic compounds, carotenoids, antioxidant activity and minerals were evaluated in 10 accessions of Cucurbita moschata landraces from the Genebank of Embrapa Temperate Agriculture (Pelotas - RS, Brazil). Twenty plants of each accession were cultivated in the field during the spring/summer of 2013/2014. After harvesting of mature fruits, the seeds were discarded and opposite longitudinal portions of the pulp were manually prepared for analysis of the bioactive compounds. For the determination of minerals, pumpkin samples were frozen in plastic bags, and after freeze-dried and milled. All analysis were performed in triplicate. The data obtained showed high genetic variability for the synthesis of phenolic compounds, carotenoids, antioxidant activity and minerals. The accessions C52, C81, C267 e C389 showed high levels of antioxidants and minerals, being recommended for use in pumpkin breeding programs. The accessions C52 and C389 are promising, especially because they present the highest levels of total carotenoids.
\end{abstract}

Keywords: pumpkin; cucurbitaceae; ex situ conservation; genetic resources; characterization.

Practical Application: Pumpkins (Cucurbita moschata) are important to the human diet due to its functional properties and benefits for the human health. Identify genetic variability for the synthesis of bioactive compounds and minerals can be useful for breeding programs, to develop cultivars with improved benefits to the consumers.

\section{Introduction}

Vegetables are a rich source of several bioactive compounds for the human diet. They are also known due to its beneficial health effects beyond its nutritional value (Sun-Waterhouse, 2011). Pumpkins (Cucurbita spp.) are widely cultivated and used as food since ancient times. Some species, such as Cucurbita moschata, Cucurbita maxima e Cucurbita pepo, revealed high levels of carotenoids (Boiteux et al., 2007; Rodriguez-Amaya et al., 2008). Cucurbita moschata covers many varieties of pumpkin that are grown both in small farms as in large areas of commercial crops in Brazil. Their fruits are used to prepare a huge diversity of regional and local dishes (Heiden et al., 2007).

Pumpkins provide vitamins of the $\mathrm{B}$ complex, calcium and phosphorus (Ramos \& Queiroz, 2005). They are important sources of carotenoids, especially $\beta$-carotene, a precursor of vitamin A. Several studies have been developed in Brazil (Rodriguez-Amaya et al., 2008) and other countries (González et al., 2001; Gwanama et al., 2002; Murkovic et al., 2002), highlighting the importance of pumpkins as a source of pro-vitamin A to human diet. Antioxidants are commonly found in fruits and vegetables and, therefore, its consumption has been associated with protection against several non-communicable diseases (Alvarez-Parrilla et al., 2012).
The population is more concern regarding to the quality of food leading to increased research on the properties and functionality of food. Many studies were performed in the last decades to validate the medicinal properties assigned to pumpkins (regarding to diabetes, hypertension, tumors and cholesterol, besides antibacterial, anthelmintic and anti-inflammatory actions). The research leads to medicinal properties of pumpkins and the mechanisms by which the compounds may reduce the risk of these diseases (Caili et al., 2006; Adams et al., 2011).

The Genebank of Cucurbitaceae from Embrapa Temperate Agriculture maintain 632 accessions of cultivated species from the genus Citrullus, Cucumis, Cucurbita, Lagenaria, Luffa, Momordica and Sicana. These, 63 are accessions of Cucurbita moschata landraces cultivated in Southern Brazil.

The aim of this study was to characterize the bioactive compounds (phenolic compounds and carotenoids), antioxidant activity and minerals $(\mathrm{Ca}, \mathrm{Mg}, \mathrm{K}, \mathrm{Cu}, \mathrm{Fe}, \mathrm{Mn}, \mathrm{Zn}$ and $\mathrm{P}$ ) in fruits of different accessions of Cucurbita moschata from southern Brazil.

\section{Material and methods}

Bioactive compounds (phenolic compounds and carotenoids), antioxidant activity and minerals $(\mathrm{Ca}, \mathrm{Mg}, \mathrm{K}, \mathrm{Cu}, \mathrm{Fe}, \mathrm{Mn}, \mathrm{Zn}$ and $\mathrm{P}$ ) were evaluated in fruits of 10 accessions of Cucurbita 
moschata belonging to the Genebank of Cucurbitaceae from Embrapa Temperate Agriculture (Table 1). The choice of these accessions was based on the passport and characterization data (mainly in the fruit characteristics such as shape, size, skin color and pulp color) and the availability of seeds for the experiment.

In September 2013, at a greenhouse, the accessions were sowed in black polystyrene bags filled with soil mixed with substrate (1:1). In October, when the plants reached the stage of two to three true leaves, 20 seedlings of each accession were transplanted to experimental field, located at Embrapa Temperate Agriculture. The plants were spaced $1.5 \mathrm{~m}$ in the line and $3 \mathrm{~m}$ between rows. They were irrigated as necessary by drip.

Fruits were harvested when they were mature. Seeds were discarded and opposite longitudinal portions of the fruits were manually prepared. Fresh pulp of each accession was used to analysis of phenolic compounds, carotenoids, antioxidant activity. All analyzes were performed in triplicate. Phenolic compounds were determined by method of Swain \& Hillis (1959) and carotenoids were quantified by the method of Talcott \& Howard (1999). Total antioxidant capacity was performed based on method of Brand-Williams et al. (1995).

To quantify minerals ( $\mathrm{Ca}, \mathrm{Mg}, \mathrm{K}, \mathrm{Cu}, \mathrm{Fe}, \mathrm{Mn}, \mathrm{Zn}$ and $\mathrm{P}$ ) the samples of each accession were freeze-dried using a lyophilizer model L 108 Litop. After lyophilized, the samples were ground and stored in plastic pots to ensure do not acquire moisture until the analysis of mineral content. The mineral quantification was performed by the method described by Tedesco et al. (1995).

The data were subjected to multivariate statistical analysis, by mean comparisons, using the statistical software SAS 9.2 (SAS Institute, 2011). Histograms were made with the aid of Microsoft Office Excel.

\section{Results and discussion}

The data obtained from chemical analysis showed the presence of genetic variability for bioactive compounds, antioxidant activity (Figure 1 and Table 2) and minerals (Table 3) in the pulp of Cucurbita moschata fruits considering the evaluated accessions.

Table 1. Cucurbita moschata accessions belonging to the Genebank of Cucurbitaceae from Embrapa Temperate Agriculture characterized regarding the bioactive compounds and minerals. Pelotas (RS), Brazil.

\begin{tabular}{cll}
\hline Accession & \multicolumn{1}{c}{ Popular Name } & \multicolumn{1}{c}{$\begin{array}{c}\text { Origin (county and state in } \\
\text { Southern Brazil) }\end{array}$} \\
\hline C52 & abóbora de pescoço & Renascença, PR \\
C81 & abóbora gigante & Ipê, RS \\
C93 & abóbora de pescoço & Alto Feliz, RS \\
C99 & abóbora de pescoço & Farroupilha, RS \\
C116 & abóbora de vaca & David Canabarro, RS \\
C136 & abóbora de pescoço & Bento Gonçalves, RS \\
C218 & abóbora & São Lourenço do Sul, RS \\
C267 & abóbora colorau & Pelotas, RS \\
C423 & abóbora de pescoço & Capão do Leão, RS \\
C389 & abóbora & Ilha dos Marinheiros, RS \\
\hline
\end{tabular}

Considering the phenolic compounds present in the pulp, the accessions were clustered in six distinct groups by analyzing the average comparison using Tukey test (Table 2). Phenolic compounds play an important role in the growth and reproduction of plants, providing protection against pathogens and predators, as well as contribute to the color and sensory characteristics of fruit and vegetables (Acunha 2013). The values of phenolic compounds found in different evaluated accessions ranged from 26.31 to $79.86 \mathrm{mg} / 100 \mathrm{~g}$ of fresh weight, presented by C116 and C389 accessions, respectively (Table 2). Tiveron (2010) analyzed the phenolic composition in vegetables and found much higher values for pumpkin C. maxima ( $160 \mathrm{mg} / 100 \mathrm{~g})$ compared to those found in this work. For other vegetables the author also found higher values, as $169 \mathrm{mg} / 100 \mathrm{~g}$ in lettuce; $128 \mathrm{mg} / 100 \mathrm{~g}$ of turmeric; $125 \mathrm{mg} / 100 \mathrm{~g}$ in cress; $150 \mathrm{mg} / 100 \mathrm{~g}$ in cucumber (which also belongs to the Cucurbitaceae family) and $120 \mathrm{mg} / 100 \mathrm{~g}$ in carrot. Zhou and $\mathrm{Yu}$ (2006) found that the content of phenolic compounds was higher in spinach and broccoli compared to carrot and pumpkin (C. maxima). Considering these data, the content of phenolic compounds in the evaluated accessions was low, which may be explained by differences in the weather or soil, but also by the methodology used in the laboratory for extraction of these compounds. The solvent used in the extraction is one factor that greatly influences the amount of compound to be extracted. For some crops such methodology is already standardized with acetone, ethanol and water or methanol. For pumpkins, as there is no methodology described, we used methanol since it is the most widely used standard solvent.

For total carotenoids, the accessions C52, C267 and C389 showed high values (Figure 1B). These accessions remained in the group with higher concentrations, presenting 36.73, 27.69 and $24.20 \mathrm{mg} / 100 \mathrm{~g}$ of fresh weight, respectively (Table 2). Such accessions, in addition to having large amounts of total carotenoids in mature fruit, also could be released as commercial varieties due to their uniformity in morphological characteristics (Figure 2). The carotenoids (yellow, orange and red pigments) are known for their beneficial effects on human diet, being the main precursors of vitamin A (antioxidant) found in various fruits and vegetables (Taylor \& Ramsay, 2005).

In different varieties of Cucurbita analyzed by Azevedo-Meleiro \& Rodriguez-Amaya (2007), a great variability in the production of carotenoids in mature fruits was found. Ramos et al. (2009) evaluated 43 landraces of pumpkin (C. maxima) and found total carotenoid content in mature fruits ranging from 10.5 to $35.6 \mathrm{mg} / 100 \mathrm{~g}$, with an average of $25.3 \mathrm{mg} / 100 \mathrm{~g}$, which are similar values comparing to those found in this study. Carotenoids content are variable in different accessions belonging to the same species, considering cultivated varieties and accessions conserved in genebanks. In 48 pumpkin accessions (Cucurbita moschata) from the Genebank of Embrapa Semi-Arid (Petrolina, PE), Souza et al. (2012) have found high levels of carotenoids (25.31 and $29.06 \mathrm{mg} / 100 \mathrm{~g}$ ), similar to those reported in this study. However, lower values were found by Amariz et al. (2009) in 14 pumpkin accessions (C. moschata) grown by traditional farmers in the Brazilian Northeast, where the total carotenoids content ranged from $1.91 \mathrm{mg} / 100 \mathrm{~g}$ to $7.85 \mathrm{mg} / 100 \mathrm{~g}$. Moura (2003) reported similar values for accessions of C. moschata (18 to $23.0 \mathrm{mg} / 100 \mathrm{~g}$ ). 


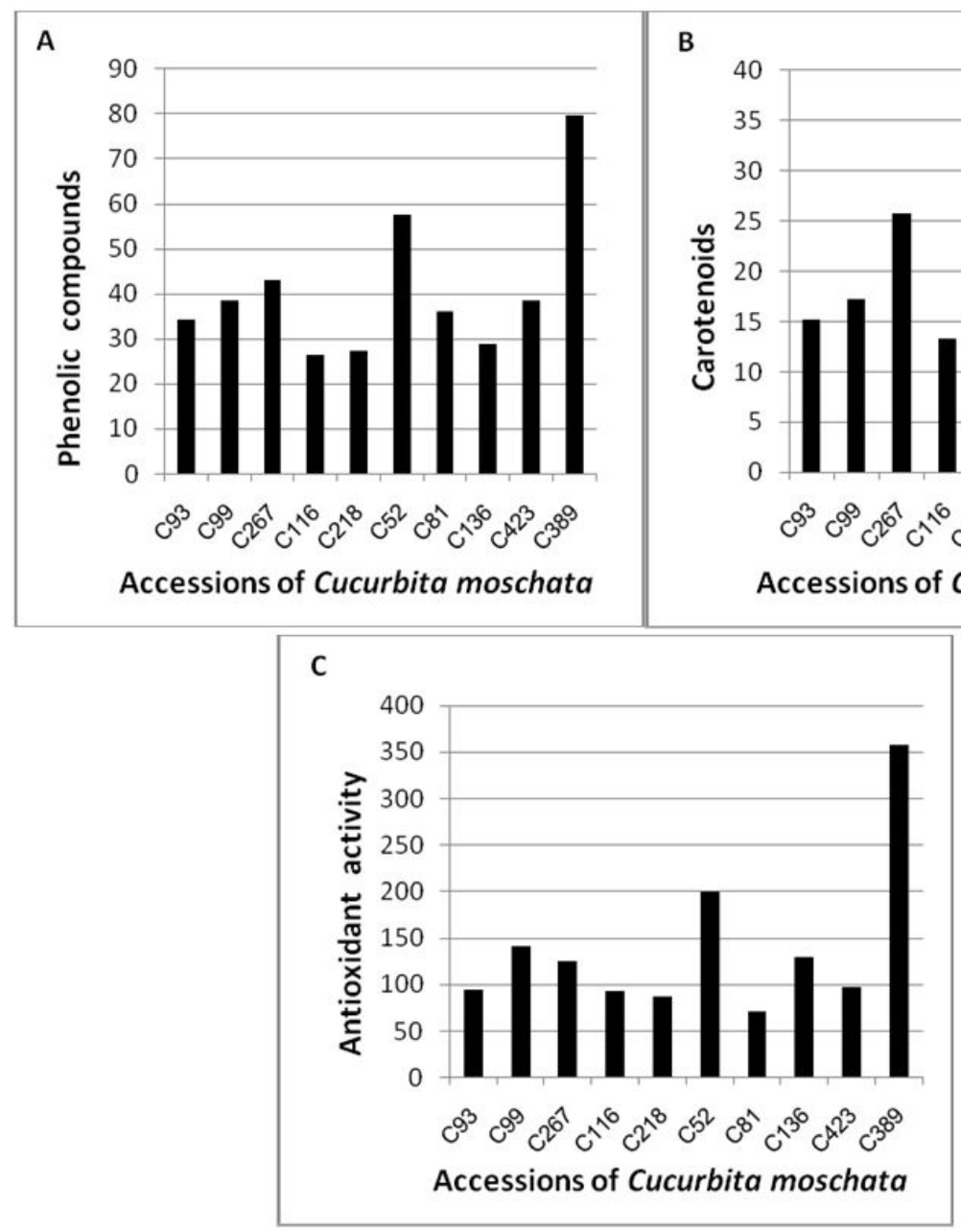

Figure 1. Bioactive compounds and antioxidant activity in accessions of Cucurbita moschata from the Genebank of Cucurbitaceae from Embrapa Temperate Agriculture, Pelotas (RS), Brazil. (A) Total phenolic compounds expressed as mg of chlorogenic acid equivalent/100g fresh weigh; (B) Total carotenoids pressed as $\mathrm{mg}$ of $\beta$-carotene equivalent $/ 100 \mathrm{~g}$ of fresh weight; (C) Total antioxidant activity expressed as $\mu \mathrm{g}$ of Trolox equivalent /g of fresh weight.

Table 2. Total phenolic compounds, total carotenoids and antioxidant activity in accessions of Cucurbita moschata from the Genebank of Cucurbitaceae from Embrapa Temperate Agriculture, Pelotas (RS), Brazil.

\begin{tabular}{cccc}
\hline Accession & Total phenolic $^{1}$ & Total Carotenoids $^{2}$ & Antioxidant activity $^{3}$ \\
\hline C52 & $57.7 \pm 0.8 \mathrm{~b}$ & $36.7 \pm 1.5 \mathrm{a}$ & $199.2 \pm 26.2 \mathrm{~b}$ \\
C81 & $36.1 \pm 1.6 \mathrm{~d}$ & $18.9 \pm 1.1 \mathrm{c}$ & $71.1 \pm 6.6 \mathrm{e}$ \\
C93 & $34.4 \pm 1.3 \mathrm{de}$ & $19.2 \pm 2.8 \mathrm{c}$ & $95.1 \pm 20.5 \mathrm{de}$ \\
C99 & $38.7 \pm 4.3 \mathrm{~cd}$ & $17.2 \pm 0.3 \mathrm{c}$ & $141.9 \pm 19.7 \mathrm{c}$ \\
C116 & $26.3 \pm 2.1 \mathrm{f}$ & $13.1 \pm 0.4 \mathrm{de}$ & $92.5 \pm 15.8 \mathrm{de}$ \\
C136 & $28.8 \pm 0.8 \mathrm{ef}$ & $13.1 \pm 0.6 \mathrm{de}$ & $129.4 \pm 3.7 \mathrm{~cd}$ \\
C218 & $27.2 \pm 3.3 \mathrm{f}$ & $10.8 \pm 0.6 \mathrm{e}$ & $87.4 \pm 9.1 \mathrm{de}$ \\
C267 & $43.06 \pm 2.4 \mathrm{c}$ & $27.7 \pm 0.1 \mathrm{~b}$ & $125.5 \pm 7.3 \mathrm{~cd}$ \\
C423 & $38.7 \pm 2.1 \mathrm{~cd}$ & $16.3 \pm 1.5 \mathrm{~cd}$ & $97.8 \pm 12.6 \mathrm{cde}$ \\
C389 & $79.9 \pm 1.1 \mathrm{a}$ & $24.2 \pm 1.2 \mathrm{~b}$ & $357.8 \pm 15.7 \mathrm{a}$ \\
\hline
\end{tabular}

${ }^{1}$ Total phenolic compounds, expressed as mg of chlorogenic acid equivalent/100g of fresh weight. ${ }^{2}$ Total carotenoids, expressed as $\mathrm{mg}$ of $\beta$-carotene equivalent $/ 100 \mathrm{~g}$ of fresh weight. ${ }^{3}$ Total antioxidant activity, expressed as $\mu \mathrm{g}$ of trolox equivalent/g of fresh weight. Means followed by the same letter in each column do not differ significantly by Tukey test at $5 \%$ error probability.
The variation found in this study was also similar to that obtained by Tamer et al. (2010) to Cucurbita maxima ( 0.16 to $25.4 \mathrm{mg} / 100 \mathrm{~g}$ ). The accession C52, which obtained higher levels for total carotenoids $(36.73 \mathrm{mg} / 100 \mathrm{~g})$, showed a value close to those found for carrot, $42.66 \mathrm{mg} / 100 \mathrm{~g}$ (Branco et al., 2005). The carrot is the main source of $\alpha$ and $\beta$-carotene, carotenoids of provitamin $A$, being the raw material most used for the extraction of $\beta$-carotene, which have various applications in the pharmaceutical and food industry (Lima et al., 2004).

Among the natural antioxidants, the vitamin E, ascorbic acid, carotenoids and especially phenolic compounds are the most important antioxidants for the human diet (Cerqueira et al., 2007). These promote a protective action against the oxidative processes in the body and are important in the interception of free radicals (Bianchi \& Antunes, 1999; Duarte-Almeida et al., 2006). The color is the most attractive quality attribute for consumers. It corresponds to one of the major judging criteria to identify the ripening of fruits and some vegetables. Plant pigments, 
Table 3. Minerals present in the pulp of fruits of Cucurbita moschata accessions belonging to the Genebank of Cucurbitaceae from Embrapa Temperate Agriculture. Pelotas, RS, Brazil.

\begin{tabular}{|c|c|c|c|c|c|c|c|}
\hline Accession & $\begin{array}{l}\text { Calcium } \\
(\mathrm{Ca})\end{array}$ & $\begin{array}{c}\text { Magnesium } \\
(\mathrm{Mg})\end{array}$ & $\begin{array}{l}\text { Potassium } \\
(\mathrm{K})\end{array}$ & $\begin{array}{c}\text { Copper } \\
(\mathrm{Cu})\end{array}$ & $\begin{array}{l}\text { Iron } \\
(\mathrm{Fe})\end{array}$ & $\begin{array}{c}\text { Manganese } \\
(\mathrm{Mn})\end{array}$ & $\begin{array}{l}\text { Zinc } \\
(\mathrm{Zn})\end{array}$ \\
\hline C52 & $2.3 \pm 0.1 \mathrm{~g}$ & $0.9 \pm 0.01 \mathrm{~d}$ & $33.9 \pm 0.7 \mathrm{f}$ & $8.1 \pm 0.371 \mathrm{ab}$ & $3.6 \pm 4.7 \mathrm{bcd}$ & $3.4 \pm 0.2 \mathrm{e}$ & $17.4 \pm 0.9 \mathrm{c}$ \\
\hline $\mathrm{C} 81$ & $5.8 \pm 0.2 \mathrm{bc}$ & $1.8 \pm 0.02 \mathrm{~b}$ & $45.09 \pm 1.6 \mathrm{de}$ & $7.1 \pm 0.2 b$ & $5.9 \pm 3.2 \mathrm{a}$ & $7.7 \pm 0.5 c$ & $40.2 \pm 5.1 \mathrm{a}$ \\
\hline C99 & 4. $\pm 0.3 \mathrm{e}$ & $0.8 \pm 0.03 \mathrm{~d}$ & $48.1 \pm 1.3 \mathrm{~cd}$ & $7.9 \pm 0.3 \mathrm{ab}$ & $3.5 \pm 6.4 \mathrm{bcd}$ & $7.0 \pm 0.5 \mathrm{~cd}$ & $20.1 \pm 3.9 \mathrm{bc}$ \\
\hline $\mathrm{C} 116$ & $4.7 \pm 0.3 \mathrm{~d}$ & $1.2 \pm 0.04 \mathrm{bcd}$ & $43.7 \pm 1.0 \mathrm{e}$ & $6.9 \pm 0.2 b$ & $3.6 \pm 4.2 \mathrm{bcd}$ & $13.9 \pm 1.5 \mathrm{a}$ & $21.9 \pm 0.6 \mathrm{bc}$ \\
\hline $\mathrm{C} 267$ & $2.9 \pm 0.2 \mathrm{f}$ & $1.1 \pm 0.03 \mathrm{~cd}$ & $36.6 \pm 1.2 \mathrm{f}$ & $6.6 \pm 0.6 b$ & $4.1 \pm 2.8 \mathrm{bc}$ & $5.7 \pm 0.6 \mathrm{~d}$ & $23.2 \pm 1.6 \mathrm{bc}$ \\
\hline $\mathrm{C} 423$ & $3.9 \pm 0.1 \mathrm{e}$ & $0.9 \pm 0.09 \mathrm{~cd}$ & $56.2 \pm 1.4 \mathrm{~b}$ & $6.7 \pm 0.3 b$ & $2.7 \pm 3.6 \mathrm{~cd}$ & $2.4 \pm 0.3 \mathrm{ef}$ & $17.1 \pm 0.8 \mathrm{c}$ \\
\hline C389 & $7.5 \pm 0.2 \mathrm{a}$ & $2.9 \pm 0.7 \mathrm{a}$ & $94.6 \pm 2.6 \mathrm{a}$ & $5.9 \pm 0.1 \mathrm{c}$ & $1.8 \pm 0.02 \mathrm{e}$ & $11.1 \pm 0.1 \mathrm{f}$ & $11.4 \pm 0.1 \mathrm{~d}$ \\
\hline
\end{tabular}

Means followed by the same letter in each column do not differ significantly by Tukey test at $5 \%$ of probability; calcium (Ca) expressed in $\mathrm{g} / \mathrm{kg}$ of dry weight; magnesium (Mg) expressed in $\mathrm{g} / \mathrm{kg}$ of dry weight; potassium (K) expressed in $\mathrm{mg} / \mathrm{kg}$ of dry weight; copper $(\mathrm{Cu}) \mathrm{in} \mathrm{mg} / \mathrm{kg}$ of dry weight; iron (Fe) expressed in $\mathrm{mg} / \mathrm{kg}$ of dry weight; manganese (Mn) in mg/kg of dry weight; zinc (Zn) in $\mathrm{mg} / \mathrm{kg}$ of dry weight.
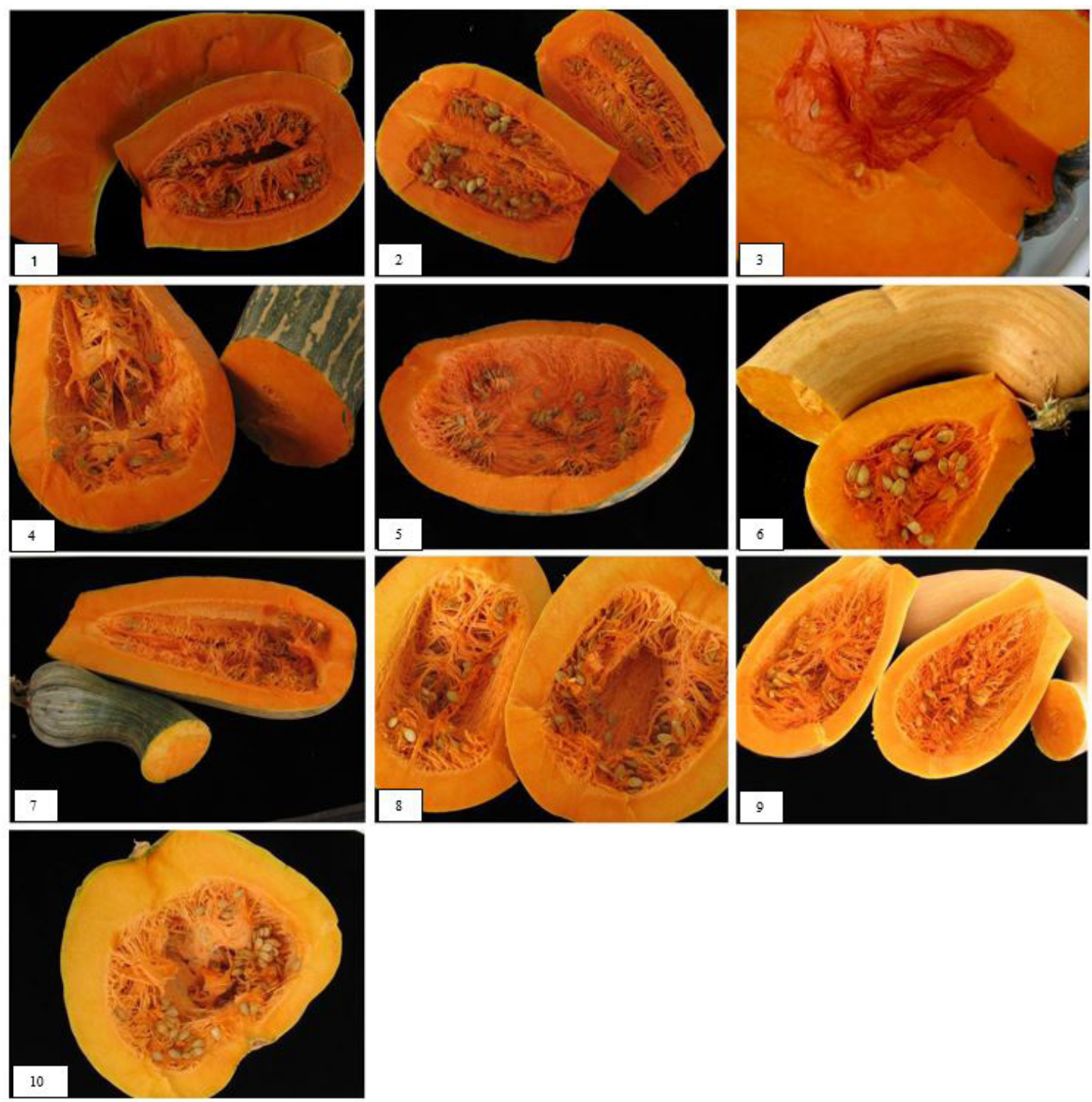

Figure 2. Pulp of the mature fruits of Cucurbita moschata accessions evaluated for bioactive compounds and minerals. (1) C52; (2) C267; (3) C389; (4) C93; (5) C81; (6) C99; (7) C423; (8) C136; (9) C116; (10) C218. Photos: Daniela Priori and Juliana Castelo Branco Villela. 
especially chlorophylls, carotenoids and anthocyanins, play a key role in the coloring of vegetables (Leme, 2012). The pulp color of cucurbits is related with carotenoids levels.

The antioxidant capacity in the evaluated accessions showed large amplitude (Figure 1C). The accessions were clustered in five groups (Table 2) by Tukey test. The accession C389 had the highest antioxidant potential $\left(357.742 \mu \mathrm{g} . \mathrm{g}^{-1}\right)$ and the lowest value was observed in the accession C81 $\left(71.09 \mu \mathrm{g} \cdot \mathrm{g}^{-1}\right)$. Tiveron (2010) found low values for antioxidant activity in pumpkin C. maxima $\left(12.7 \mu \mathrm{g} . \mathrm{g}^{-1}\right)$ when compared to those found in this work. In the accessions of $C$. moschata evaluated in this work, the carotenoids content was higher in those whose pulp was intensively orange (Figure 2).

Content of phenolic compounds and antioxidant activity showed a strong correlation $(\mathrm{r}=0.801)$ in accessions of Cucurbita moschata (Figure 3). This result was similar to that reported by Koca \& Karadeniz (2009), which observed linear correlation $(\mathrm{r}=0.981)$ between antioxidant activity and phenolic compounds content in blueberry fruits. Vizzotto et al. (2007) found strong correlation between phenolic compounds and antioxidant activity in peach $(\mathrm{r}=0.85)$ and prunus $(\mathrm{r}=0.74)$.

In contrast, the correlation between antioxidant activity and carotenoids content was low (Figure 3B). Similarly, Amariz (2011) found no correlation between antioxidant activity and carotenoids content in accessions of Cucurbita moschata from the Genebank of Cucurbitaceae from Embrapa Semi-Arid.

The mineral elements are widely distributed in nature and play important roles in the human body. Although present in the diet, some minerals are not eaten in adequate amounts to meet their daily metabolic needs (Sichiere et al., 2000). The consumption of vegetables is important to ensure the enough intake, because in these foods the minerals are present in higher concentration (Moreira, 2006).

According to Franco (2004), the composition of human body is $96 \%$ hydrogen, carbon, oxygen and nitrogen compounds, which constitute the called immediate principles: water, protein, carbohydrates and lipids. The remaining $4 \%$ are minerals, and only calcium (1.5\%) and phosphorus (1\%) account for $2.5 \%$, while the $1.5 \%$ remaining are all other minerals, as potassium, sodium, manganese, magnesium, chlorine, sulfur, zinc, copper and other. The human body under normal conditions excretes daily from 20 to $30 \mathrm{~g}$ of minerals and needs an immediate replacement through food.

The content of calcium (Ca) in C. moschata accessions evaluated in this work ranged from $2.26 \mathrm{~g} / \mathrm{kg}$ to $7.49 \mathrm{~g} / \mathrm{kg}$ (accession C389) of dry weight (Table 3). Kalluf (2006) evidenced calcium levels similar to those found in this study characterizing pumpkin varieties (C. moschata) and reported $6.78 \mathrm{~g} / \mathrm{kg}$ of dry
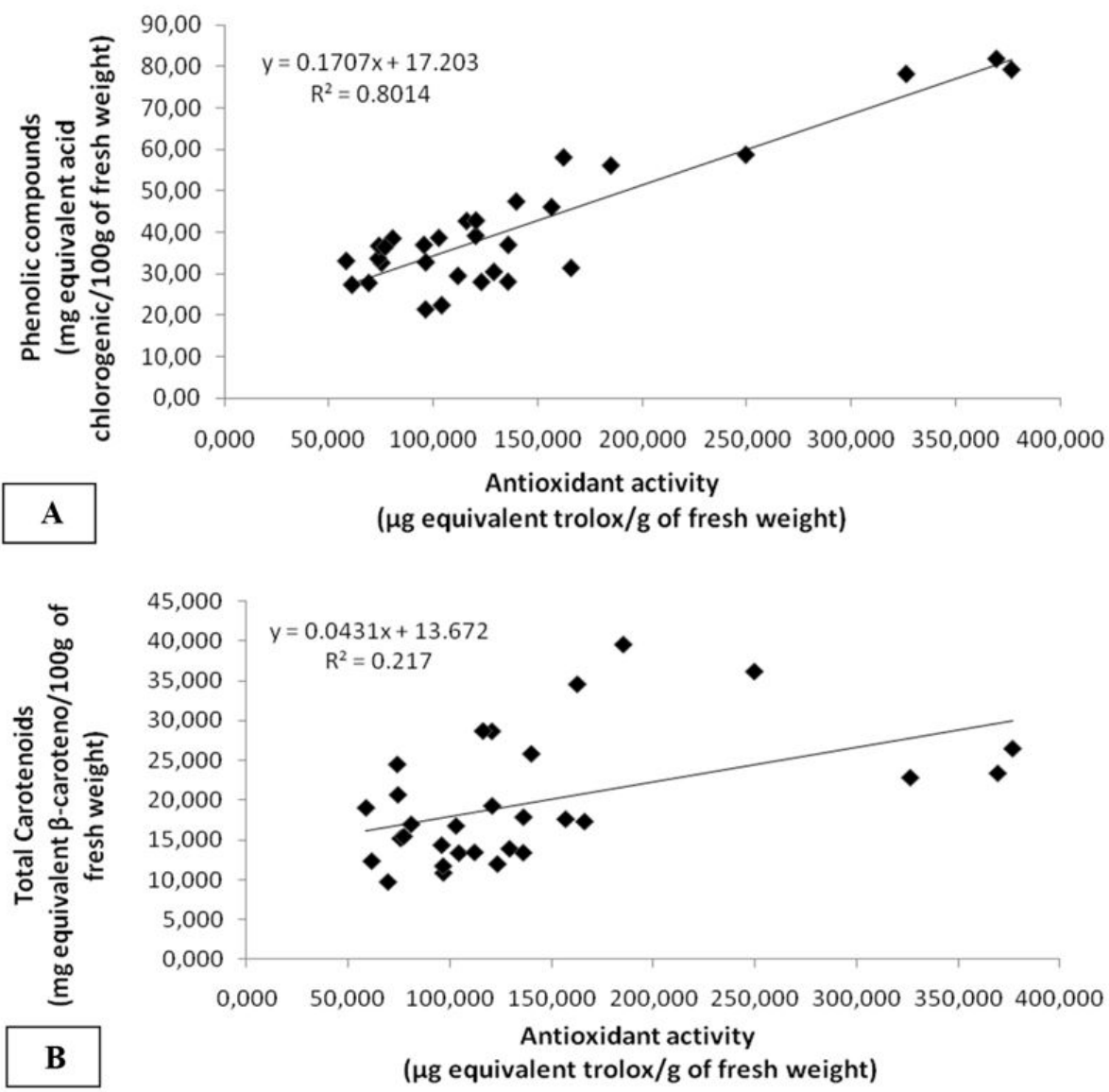

Figure 3. Correlation between bioactive compounds and accessions of Cucurbita moschata. (A) Correlation between antioxidant activity and phenolic compounds; (B) Correlation between antioxidant activity and total carotenoids. 
weight as average value. Other papers have reported $2.5 \mathrm{~g} / \mathrm{kg}$ of dry weight (United States Department of Agriculture, 2005) and $1.8 \mathrm{~g} / \mathrm{kg}$ of fresh weight (Universidade Estadual de Campinas \& Núcleo de Estudos e Pesquisas em Alimentação, 2004) also for C. moschata. Approximately $99 \%$ of calcium are present in the bones and teeth. The remaining $1 \%$ of calcium is in the blood, in the extracellular fluid and into the cells of all tissue, once it regulates many important metabolic functions.

For magnesium, the values ranged from $0.86 \mathrm{~g} / \mathrm{kg}$ (accession C52) and $2.84 \mathrm{~g} / \mathrm{kg}$ dry weight (accession C389). Magnesium can be found in a wide variety of foods and beverages such as nuts, fruits, vegetables, tubers, seeds, whole grains, coffee and tea. Whole grains provide an average $0.25 \mathrm{~g} / \mathrm{kg}$ and spinach, $0.15 \mathrm{~g} / \mathrm{kg}$ (Gropper et al., 2009). $55 \%$ to $60 \%$ of the magnesium body is found in bone tissue, associated with phosphorus and calcium and the remaining on the bone surface as amorphous form (Cônsolo, 2015). Universidade Estadual de Campinas \& Núcleo de Estudos e Pesquisas em Alimentação (2011) reported lower values $(0.007 \mathrm{~g} / \mathrm{kg})$ for magnesium concentration in pumpkin (Cucurbita moschata) compared to those found in our study, but this author used fresh weight.

The evaluated pumpkin accessions showed potassium $(\mathrm{K})$ content ranging from $33.97 \mathrm{mg} / \mathrm{kg}$ (accession C52) to $94.57 \mathrm{mg} / \mathrm{kg}$ (accession C389) of dry weight. Potassium is a very important mineral for the body, and its recommended intake average for adults is $2.0 \mathrm{mg} /$ day (Franco, 2004). It is a very abundant element in most foods. Universidade Estadual de Campinas \& Núcleo de Estudos e Pesquisas em Alimentação (2006) reported potassium content of $21.3 \mathrm{mg} / \mathrm{kg}$ for C. maxima and $24 \mathrm{mg} / \mathrm{kg}$ for C. moschata, both values lower than those found in this work for the evaluated accessions. However, we need to consider that author used fresh weight and we used dry weight.

The copper (Cu) levels varied from $5.78 \mathrm{mg} / \mathrm{kg}$ to $8.93 \mathrm{mg} / \mathrm{kg}$ of dry weight, emphasizing the accession $\mathrm{C} 136$ with the highest content. Nascimento et al. (2013) evaluated pumpkin accessions (C. pepo) and found lower levels of copper $(2.0 \mathrm{mg} / \mathrm{kg})$ compared to those found in this work.

For the manganese (Mn), the values varied from $2.33 \mathrm{mg} / \mathrm{kg}$ (accession C116) to $13.94 \mathrm{mg} / \mathrm{kg}$ of dry weight (accession C423). Besides being present in the soil, manganese is also present in large amounts in food such as nuts $(4.7 \mathrm{mg} / \mathrm{kg})$, cereals $(4.1 \mathrm{mg} / \mathrm{kg})$, grains $(4.1 \mathrm{mg} / \mathrm{kg})$, fruit $(0.2-10.4 \mathrm{mg} / \mathrm{kg})$, beef, fish, and eggs (0.1-3.99 mg/kg) (Martins \& Lima, 2001; Gropper, Smith \& Groff, 2009). The values found in this study for manganese were higher when compared to the values $(7.0 \mathrm{mg} / \mathrm{kg})$ reported by Universidade Estadual de Campinas \& Núcleo de Estudos e Pesquisas em Alimentação (2011) for Cucurbita moschata considering fresh weight.

The evaluated accessions also showed variation for iron $(\mathrm{Fe})$ and zinc $(\mathrm{Zn})$. The iron content ranged from $1.77 \mathrm{mg} / \mathrm{kg}$ to $5.90 \mathrm{mg} / \mathrm{kg}$ of dry weight (Table 3). The accession C81 had the highest value. For zinc $(\mathrm{Zn})$ the variation between the accessions was higher, from $11.3 \mathrm{mg} / \mathrm{kg}$ to $40.18 \mathrm{mg} / \mathrm{kg}$ of dry weight, also highlighting the accession C81 with the highest value. C. moschata proved to be a good source of iron and zinc when considered that the daily recommendations for consumption are about $7 \mathrm{mg}$ and $15 \mathrm{mg}$, respectively (Stella 2005). Regarding the zinc content for C. moschata, Kalluf (2006) reported $59.48 \mathrm{mg} / \mathrm{kg}$, a higher value than $38 \mathrm{mg} / \mathrm{kg}$ referenced by the United States Department of Agriculture (2005) and $27 \mathrm{mg} / \mathrm{kg}$ of fresh weight found by Universidade Estadual de Campinas \& Núcleo de Estudos e Pesquisas em Alimentação (2004). Is worth mentioning that the zinc content in the present study was high $(40,18 \mathrm{mg} / \mathrm{kg})$ also in the C81 accession. The iron content found in this work was low compared to that found by Kalluf (2006), $99.3 \mathrm{mg} / \mathrm{kg}$, and to that reported by the United States Department of Agriculture (2005), $95 \mathrm{mg} / \mathrm{kg}$. Iron is a microelement and one of the most important minerals popularly cited as in the food. An example of vegetables considered rich iron sources are watercress and spinach (Franco, 2004).

The accession C389 presented the highest content of calcium, magnesium and potassium among all accessions. In turn, the accession C81 showed the highest levels of iron and zinc. Among the important functions of minerals in the human body are muscle contractility, blood clotting, digestive processes and transport of oxygen. However, despite its importance, little is known about the content of minerals in foods, the interactions between them and with other compounds as well as their bioavailability and the effect of different forms of culinary and industrial preparation about these. This deficiency of information is considerable even for basic and conventional foods (Franco, 2004).

\section{Conclusions}

There is genetic variability for bioactive compounds and minerals in the pulp of the mature fruits of different Cucurbita moschata accessions from the Genebank of Cucurbitaceae from Embrapa Temperate Agriculture.

The accessions C52, C81, C267 and C389 present high levels of antioxidants compounds and minerals and are recommended for use in breeding programs. The accessions C52 and C389 are especially promising because they show high levels of carotenoids.

The accessions C52 and C389 are especially promising, because C52 stand out for its high production of carotenoids and C389 presented the highest concentration of phenolic compounds, antioxidant activity, contents of calcium, magnesium and potassium. These accessions are excellent sources of natural antioxidant compounds and both could be exploited in breeding programs to obtain cultivars with high potential for promotion the consumer's health.

\section{Acknowledgements}

The authors thank CNPq and CAPES by providing scholarships and financial support.

\section{References}

Acunha, T. S. (2013). Variabilidade metabólica em pimentas (Capsicum spp.): destaque para capsaicinoides por CLAE/FL/EM/EM (Dissertação de mestrado, 72 p.). Universidade Federal de Pelotas, Pelotas.

Adams, G. G., Mohammad, S. K., David, A. G., Guy, A. C., Gordon, A. M., \& Stephen, E. H. (2011). The hypoglycaemic effect of pumpkins as anti-diabetic and functional medicines. Food Research International, 44(4), 862-867. http://dx.doi.org/10.1016/j.foodres.2011.03.016. 
Alvarez-Parrilla, E., Rosa, L. A., Amarowicz, R., \& Shahidi, F. (2012). Protective effect of fresh and processed Jalapeño and Serrano peppers against food lipid and human LDL cholesterol oxidation. Food Chemistry, 133(3), 827-834. http://dx.doi.org/10.1016/j. foodchem.2012.01.100.

Amariz, A. (2011). Qualidade, compostos bioativos e atividade antioxidante de frutos de acessos de jerimum de leite (Cucurbita moschata) pertencentes ao Banco Ativo de Germoplasma de Cucurbitáceas da Embrapa Semiárido (Dissertação de mestrado, 134 p.). Universidade Federal Rural do Semiárido, Mossoró.

Amariz, A., Lima, M. A. C., Borges, R. M. E., Belém, S. F., Passos, M. C. L. M. S., Trindade, D. C. G., \& Ribeiro, T. P. (2009). Caracterização da qualidade comercial e teor de carotenoides em acessos de abóbora. Horticultura Brasileira, 27, 541-547. Retrieved from http://www. alice.cnptia.embrapa.br/alice/bitstream/doc/575871/1/OPB2590.pdf

Azevedo-Meleiro, C. H., \& Rodriguez-Amaya, D. B. (2007). Qualitative and quantitative differences in carotenoid composition among Cucurbita moschata, Cucurbita maxima, and Cucurbita pepo. Journal of Agricultural and Food Chemistry, 55(10), 4027-4033. http://dx.doi. org/10.1021/jf063413d. PMid:17444652.

Bianchi, M. L. P., Antunes, L. M. G. (1999). Radicais livres e os principais antioxidantes da dieta. Revista de Nutrição, 12(2), 123-130.

Boiteux, L. S., Nascimento, W. M., Fonseca, M. E. N., Lana, M. M., Reis, A., Mendonca, J. L., Lopes, J. F., \& Reifschneider, F. J. B. (2007). 'Brasileirinha': Cultivar de abóbora (Cucurbita moschata) de frutos bicolores com valor ornamental e aptidão para consumo verde. Horticultura Brasileira, 25(1), 103-106. http://dx.doi.org/10.1590/ S0102-05362007000100020.

Branco, E. G., Argandoña, E. J. S., Sávio, J., \& Ramos, S. (2005). Efeito do branqueamento e da solução desidratante na desidratação osmótica de fatias de cenoura. Revista Ciências Exatas e Naturais, 7(1), 7790. Retrieved from http://www.abhorticultura.com.br/biblioteca/ arquivos/Download/Biblioteca/46_0580.pdf

Brand-Williams, W., Cuvelier, M. E., \& Berset, C. (1995). Use of a free radical method to evaluate antioxidant activity. LebensmittelWissenschaft \& Technologie, 28(1), 25-30. http://dx.doi.org/10.1016/ S0023-6438(95)80008-5.

Caili, F., Huan, S., \& Quanhong, L. (2006). A review on pharmacomogical actives and utilization technomogies of pumpkin. Plant Foods for Human Nutrition (Dordrecht, Netherlands), 61(2), 73-80. http:// dx.doi.org/10.1007/s11130-006-0016-6. PMid:16758316.

Cerqueira, F. M., Medeiros, M. H. G., \& Augusto, O. (2007). Antioxidantes dietéticos: controvérsias e perspectivas. Química Nova, 30(2), 441449. Retrieved from http://www.scielo.br/scielo.php?script=sci_ar ttext\&pid=S0100-40422007000200036

Cônsolo, F. Z. (2015). Avaliação das concentrações de magnésio, zinco, cobre, ferro, manganês, alumínio, cromo, cádmio, níquel, cobalto e molibdênio nas hortaliças tuberosas comercializadas e consumidas em Mato Grosso do Sul (Tese de doutorado, 126 p.). Universidade Federal de Mato Grosso do Sul, Campo Grande.

Duarte-Almeida, J. M., Santos, R. J., Genovese, M. I., Lajolo, F. M. (2006). Avaliação da atividade antioxidante utilizando sistema $\beta$-Caroteno/ ácido linoléico e método de seqüestro de Radicais DPPH. Ciência e Tecnologia de Alimentos, 26(2), 446-452.

Franco, G. (2004). Tabela de composição química dos alimentos (307 p.). São Paulo: Atheneu. Retrieved from http://www.unicamp. br/nepa/taco/contar/taco_4_edicao_ampliada_e_revisada. pdf?arquivo=taco_4_versao_ampliada_e_revisada.pdf

González, E., Montenegro, M. A., Nazareno, M. A., \& López de Mishima, B. A. (2001). Carotenoid composition and vitamin A value of an
Argentinian squash (Cucurbita moschata). Archivos Latinoamericanos de Nutricion, 51(4), 395-399. PMid:12012567.

Gropper, S. S., Smith, J. L., \& Groff, J. L. (2009). Advanced nutritional and human metabolism (5th ed., pp. 488-510). Belmont: Wadsworth.

Gwanama, C., Lungu, D., Nichterlein, K., \& Simawachi, W. (2002). Variation of fruit Beta-carotene content of tropical pumpkin (Cucurbita moschata Duch.) landraces in Zambia. Noticiário de Recursos Fitogenéticos, 129, 44-46. Retrieved from https:/getinfo. de/en/search/id/BLSE\%3ARN122390147/

Heiden, G., Barbieri, R. L., \& Neitzke, R. S. (2007). Chave para identificação das espécies de abóboras (Cucurbita, Cucurbitaceae) cultivadas no Brasil (31 p., Embrapa Clima Temperado - Documentos, 197) Pelotas: Embrapa Clima Temperado.

Kalluf, V. H. (2006). Desidratação da polpa de abóbora (Cucurbita moschata) e seus teores em beta-caroteno (Dissertação mestrado, 59 p.). Programa de Pós-graduação em Tecnologia em Alimentos, Universidade Federal do Paraná, Curitiba.

Koca, I., \& Karadeniz, B. (2009). Antioxidant properties of blackberry and blueberry fruits grown in the Black Sea Region of Turkey. Scientia Horticulturae, 121(4), 447-450. http://dx.doi.org/10.1016/j. scienta.2009.03.015.

Leme, S. C. (2012). Qualidade pós-colheita de pimentões produzidos em sistema orgânico (Tese de doutorado, 117 p.). Universidade Federal de Lavras, Lavras.

Lima, K. S. C., Lima, A. L. S., Freitas, L. C., Della-Modesta, R. C., \& Godoy, R. L. O. (2004). Efeito de baixas doses de irradiação nos carotenóides majoritários em cenouras prontas para o consumo. Ciência e Tecnologia de Alimentos, 24(2), 183-193. http://dx.doi. org/10.1590/S0101-20612004000200005.

Martins, I., \& Lima, I. V. (2001). Ecotoxicologia do manganês e seus compostos. Cadernos de Referência Ambiental, 7, 18-42.

Moreira, T. R. (2006). Análise de perdas de minerais em hortaliças submetidas a dois métodos de cocção (Monografia). Centro Universitário Franciscano, Santa Maria. Retrieved from http://www.nutricaoativa. com.br/arquivos/monografia3.pdf

Moura, M. C. C. L. (2003). Identificação de fontes de resistência ao potyvirus ZYMV e diversidade genética e ecogeográfica em acessos de abóbora (Tese de doutorado, 86 p.). Universidade Federal de Viçosa, Viçosa.

Murkovic, M., Mulleder, U., \& Neunteufl, H. (2002). Carotenoid content in different varieties of pumpkis. Journal of Food Composition and Analysis, 15(6), 633-638. http://dx.doi.org/10.1006/jfca.2002.1052.

Nascimento, B. L. M., Gomes, D. R. C. S., Araújo, S. S., Oliveira, J. D. (2013). Extração sequencial de ferro e cobre em olerícolas orgânicas e convencionais comercializadas em Imperatriz - Maranhão. Revista ACSA, 9(3), 1-7.

Ramos, S. R. R., \& Queiroz, M. A. (2005). Recursos genéticos de abóbora no Nordeste brasileiro. In M. C. Lima, Recursos genéticos de hortaliças: riquezas naturais (pp. 99-116). São Luís: Instituto Interamericano de Cooperação para a Agricultura.

Ramos, S. R. R., Carvalho, H. W. L., Queiroz, M. A., Santos, E. D., Silva, H. M., Trindade, B. C., Passos, R. S., Santos, J. S., Nutti, M. R., Brito, K. M., Kimura, M., \& Oliveira, I. R. (2009). Avaliação preliminar de acessos locais de abóbora para teores de carotenóides totais e sólidos solúveis. In Reunião Anual de Biofortificação no Brasil. Aracaju: Embrapa Tabuleiros Costeiros. (Documentos, 148).

Rodriguez-Amaya, D. B., Kimura, M., Godoy, H. T., \& Amaya Farfan, J. (2008). Updated Brazilian database on food carotenoids: factors affecting Carotenoid composition. Journal of Food Composition and Analysis, 21(6), 445-463. http://dx.doi.org/10.1016/j.jfca.2008.04.001. 
SAS Institute. (2011). The SAS system for windows: release 9.2. Cary: SAS Institute.

Sichiere, R., Coitinho, D. C., Monteiro, J. B., \& Coutinho, W. F. (2000). Recomendações de alimentação e nutrição saudável para a população brasileira. Arquivos Brasileiros de Endocrinologia e Metabologia, 44(3), 227-232.

Souza, C. O., Menezes, J. D. S., Ramos, D. C. No., Assis, J. G. A., Silva, S. R., \& Druzian, J. I. (2012). Carotenoides totais e vitamina A de cucurbitáceas do Banco Ativo de Germoplasma da Embrapa Semiárido. Ciência Rural. Santa Maria, 42(5), 926-933. http://dx.doi. org/10.1590/S0103-84782012005000024.

Stella, R. A. (2005). Importância dos sais minerais para o organismo. Retrieved from http://wwwl.uol.com.br/cyberdiet/colunas/030725_ nut_saisminerais.htm

Sun-Waterhouse, D. (2011). The development of fruit-based functional foods targeting the health and wellness market: a review. International Journal of Food Science \& Technology, 46(5), 899-920. http://dx.doi. org/10.1111/j.1365-2621.2010.02499.x.

Swain, T., \& Hillis, W. E. (1959). The phenolic constituents of Prunus domestica: the quantitative analysis of phenolic constituents. Journal of the Science of Food and Agriculture, 10(1), 63-68. http://dx.doi. org/10.1002/jsfa.2740100110.

Talcott, T. S., \& Howard, R. L. (1999). Phenolic autoxidation is responsible for color degradation in processed carrot pure. Journal of Agricultural and Food Chemistry, 47(5), 2109-2115. http://dx.doi.org/10.1021/ jf981134n. PMid:10552504.

Tamer, C. E., Incedayi, B., Parseker Yönel, S., Yonak, S., \& Çopur, Ö. U. (2010). Evaluation of several quality criteria of low calorie pumpkin dessert. Notulae Botanicae Horti Agrobotanici, 38, 76-80.

Taylor, M., \& Ramsay, G. (2005). Carotenoid biosynthesis in plant storage organs: recent advances and prospects for improving plant food quality. Physiologia Plantarum, 124(2), 143-151. http://dx.doi. org/10.1111/j.1399-3054.2005.00509.x.
Tedesco, J. M., Gianelo, C., Carlos, A. B., Bohnen, H., \& Volkweiss, S. J. (1995). Análises de solo, plantas e outros materiais (2. ed., Boletim técnico, no. 5). Porto Alegre: Departamento de Solos/UFRGS. Retrieved from http://pt.scribd.com/doc/41082320/Tedesco-etal-1995\#scribd

Tiveron, A. P. (2010). Atividade antioxidante e composição fenólica de legumes e verduras consumidas no Brasil (Dissertação mestrado, 102 p.). Escola Superior de Agricultura Luiz de Queiroz de Piracicaba, Piracicaba.

United States Department of Agriculture - USDA. (2005). National nutrient database for standard reference: Realease 18. Washington, DC: USDA. Retrieved from http://www.nal.usda.gov/fnic/foodcomp/ cgi-bin/list_nut_edit.pl

Universidade Estadual de Campinas - UNICAMP; Núcleo de Estudos e Pesquisas em Alimentação - NEPA. (2004). Tabela brasileira de composição de alimentos - TACO (42 p.). Campinas: NEPA/ UNICAMP. Retrieved from http://www.unicamp.br/nepa/taco/ contar/taco_4_edicao_ampliada_e_revisada.pdf?arquivo=taco_4 versao_ampliada_e_revisada.pdf

Universidade Estadual de Campinas - UNICAMP; Núcleo de Estudos e Pesquisas em Alimentação - NEPA. (2011). Tabela Brasileira de Composição de Alimentos - TACO (4. ed., 161 p.). Campinas: NEPA/UNICAMP.

Universidade Estadual de Campinas - UNICAMP; Núcleo de Estudos e Pesquisas em Alimentação - NEPA. (2006). Tabela Brasileira de Composição de Alimentos - TACO (2. ed., 113 p.). Campinas: NEPA/UNICAMP.

Vizzotto, M., Zevallos, L. C., \& Byrne, D. H. (2007). Large variation found in the Phytotchemical and Antioxidant Activity of peach and plum germoplasm. Journal of the American Society for Horticultural Science, 132(3), 334-340.

Zhou, K., \& Yu, L. (2006). Total phenolic contentes and antioxidante properties of commonly consumed vegetables grown in Colorado. Food Science and Tecnology, Maryland, 39(10), 1155-1162. 